\title{
Transatlantica
}

Revue d'études américaines. American Studies Journal

Hors-série | 2021

Numéro anniversaire : 20 ans de la revue

\section{A Response to the Roundtable of American Studies Journals from the Editorial Board of the Revue Française d'Études Américaines}

Nicholas Manning

\section{CpenEdition}

Journals

Electronic version

URL: https://journals.openedition.org/transatlantica/17545

DOI: 10.4000/transatlantica. 17545

ISSN: $1765-2766$

Publisher

Association française d'Etudes Américaines (AFEA)

\section{Electronic reference}

Nicholas Manning, "A Response to the Roundtable of American Studies Journals from the Editorial Board of the Revue Française d'Études Américaines", Transatlantica [Online], Hors-série I 2021, Online since 01 October 2021, connection on 13 October 2021. URL: http://journals.openedition.org/ transatlantica/17545; DOI: https://doi.org/10.4000/transatlantica. 17545

This text was automatically generated on 13 October 2021.

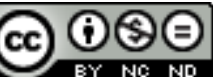

Transatlantica - Revue d'études américaines est mise à disposition selon les termes de la licence Creative Commons Attribution - Pas d'Utilisation Commerciale - Pas de Modification 4.0 International 


\title{
A Response to the Roundtable of American Studies Journals from the Editorial Board of the Revue Française d'Études Américaines
}

\author{
Nicholas Manning
}

1 What is immediately striking in the stimulating responses to this roundtable discussion is their relative agreement with regard to many of the pressing challenges and imperatives of journal culture in our present academic moment. For better or for worse, it appears that we have somewhat left behind the agonistic years of competing ideological frameworks-whether sociopolitical, theoretical, or more often a complex interweaving of both-that so informed many ongoing "journal wars," pitting academic publications against one another throughout the evolutions of the modern university.

2 Such conflicts were, not unproblematically, very often fueled by the convictions and identities of such journals' respective contributors and editors in chief. We may think for instance of the post-war role of a publication such as The Kenyon Review under the editorship of John Crowe Ransom. In an era of ideologically-aligned publications, it was hardly controversial for editors such as Ransom to frame a journal as an organ and living example of, for instance, New Critical method. In spite of the New Critics' claim to the contrary, these debates were obviously political, and not merely formalist, in nature, though they ironically often turned around the impossibility of occupying supposedly neutral formalist positions either in historical argument or literary and cultural analysis. It is safe to say, however, that this didactic use of a journal as an explicit arbiter of right practice, according to a defined Theory with a capital $\mathrm{T}$, is not a perspective that any of us appear to share, and this distinction seems, in itself, revealing.

This should not be taken to imply that there is any sort of artificial consensus or homogeneity around the political and intellectual differences that our contemporary publications do represent. It is not to say, either, that journals do not have more or less 
implicit orientations-whether towards continental or analytic traditions, historicizing or formalizing methodologies, or approaches couched in turn as materialist, affective, feminist, new historicist, etc.- only that, in many respects, the enemy to their survival now appears greater, namely the broader doctrinaire currents that today threaten the viability of academic journal culture as a whole, whatever its specific stripes.

There thus may seem something rather quaint, in our present context, about some of the major divisions of journal culture even in the recent past, and throughout much of the twentieth century. One primary reason for this, as underlined by almost all contributors to this discussion at various points, is that the experience of journal editing in our current academic condition is simply indissociable from the intensifying pressures, at once ideological and socioeconomic, of which we are all the unhappy subjects: of time and money, and of time as money. The framing of a general axiological question-such as "What values does your journal stand for?"-is thus often in itself partial, in that, though such macro positionings may be evident in each editorial choice, the day-to-day grind of editorial labor more closely resembles a Sisyphus-esque struggle to impede the flow from an hourglass with fewer and fewer grains of sand.

Such imperatives were simply not felt to the same degree in the academic cultures of previous eras, and their effect may be felt, in myriad subtle ways, at every level of our journals' processes: from the ever-harder-to-find peer-reviewers-themselves with no more free time to give to us freely-to contributors with less and less available energy or means to devote to potentially long processes of revision and further research.

These observations are not to indulge in a complacent outpouring of complaint. Rather, it is to claim that in this particular circumstance, paradoxically, the so-called "defense" of academic culture-which for so long may have seemed a reactionary or rear-guard stance, inevitably involved in the perpetuation of hegemony-often becomes no more than a necessary position, even when one is aware of its dangers, even when the disparities which it often masks remain ever-present.

7 In line with such a delicate equilibrium, as one of the two journals-with Transatlantica - published and financially sustained by the Association française d'études américaines, the Revue Française d'Études Américaines features the contributions of scholars from vastly different intellectual traditions, and with concomitantly diverse disciplinary allegiances. With regard to the journals represented in this discussion, our role as editors in chief is thus somewhat specific: since one or several coordinators take charge of each dossier, our task often seems to be that of hopefully useful intermediaries: between coordinators and contributors, contributors and peer-reviewers, and ultimately between the journal itself and its broader readership within the American studies community in France and abroad.

8 Though this interstitial positioning is indeed the case for all editors of academic journals, and in some way defines the editorial métier as one of concurrent authority and subservience-in a positive sense-to other colleagues' aims and expertise, its degree is only increased in a context where it is each issue's coordinators who, ideally, come to the journal with a specific vision: with a fundamental question that must be broached. Whether this spotlight is placed on Arab American literatures and the question of home and belonging, or the role of nudity in contemporary performanceto mention just two forthcoming dossiers-our role is primarily to accompany the realization of this intention in a communal context of simultaneous evaluation and exchange. 
9 Such an emphasis on positive values is hopefully not to create a naïve vision of inclusivity, which brushes over the disagreements at the heart of scholarship. But it is to describe a moment in which the aims of our pluralized journal cultures are always framed within, if not entirely united by, the survival of a form of cultural and intellectual dialogue whose continued existence is in no way guaranteed.

\section{AUTHOR}

\section{NICHOLAS MANNING}

Université Grenoble Alpes, Institut universitaire de France 